\title{
Salicylic acid relieves the effect of saline stress on soursop morphysiology
}

\section{Ácido salić́lico alevia o efeito do estresse salino na morfofisiologia da gravioleira}

\author{
André Alisson Rodrigues da Silva ${ }^{1 *} \mathbb{D}$, Geovani Soares de Lima ${ }^{1}\left(\mathbb{D}\right.$, Carlos Alberto Vieira de Azevedo ${ }^{1}$, \\ Hans Raj Gheyi ${ }^{1}$, Allesson Ramos de Souza' ${ }^{1}$, Pedro Dantas Fernandes ${ }^{1}(\mathbb{D}$
}

\author{
'Universidade Federal de Campina Grande/UFCG, Campina Grande, PB, Brasil \\ *Corresponding author: andrealisson_cgpb@hotmail.com \\ Received in April 2, 2021 and approved in May 27, 2021
}

\begin{abstract}
The cultivation of soursop has increased in recent years due to the advance of agribusiness and due to its use by the pharmaceutical industry. As a source of vitamin C, calcium, carbohydrates and antioxidant substances, soursop helps to protect the human body against oxidative stress, acting in the prevention of a series of chronic degenerative disorders. In this context, the objective of present study was to evaluate the effects of foliar sprays with salicylic acid to mitigate the effects of salt stress on the morphophysiology of soursop. The study was conducted in a greenhouse, in a randomized block design and a $5 \times 4$ factorial arrangement, with five levels of electrical conductivity of irrigation water - ECW (0.8-control; 1.6; 2.4; 3.2 and $\left.4.0 \mathrm{dS} \mathrm{m}^{-1}\right)$ and four concentrations of salicylic acid - SA $(0 ; 1.2 ; 2.4$ and $3.6 \mathrm{mM}$ ), with three replicates. Foliar application of SA at concentrations between 1.2 and $1.6 \mathrm{mM}$ mitigated the effects of salt stress on stomatal conductance, $\mathrm{CO}_{2}$ assimilation rate, transpiration and instantaneous carboxylation efficiency of soursop at 480 days after transplanting. Spraying with SA at concentrations between 1.3 and $1.6 \mathrm{mM}$ induced acclimatization to salt stress in soursop plants, since the percentage of intercellular electrolyte leakage was reduced and the growth was favored by the application of SA, even when exposed to salinity. Irrigation with ECw above $0.8 \mathrm{dS} \mathrm{m}^{-1}$ reduced the relative water content in the leaves of soursop cv. Morada Nova.
\end{abstract}

Index terms: Annona muricata L; salinity; abiotic stress; elicitor.

\begin{abstract}
RESUMO
O cultivo da graviola tem aumentado nos últimos anos em função do avanço da agroindústria e pela utilização na indústria farmacêutica. Em razão da fruta ser fonte de vitamina C, cálcio, carboidratos e substâncias antioxidantes, além de auxiliar na proteção contra o estresse oxidativo, atuando na prevenção de uma série de distúrbios crônico degenerativos. Nesse contexto, objetivou-se avaliar os efeitos de pulverizações foliares com o ácido salicílico na mitigação dos efeitos do estresse salino na morfofisiologia da gravioleira. O estudo foi conduzido em casa de vegetação, no delineamento de blocos casualizados e arranjo fatorial $5 \times 4$, com cinco níveis de condutividade elétrica da água de irrigação - CEa (0,8-controle; 1,6; 2,4; 3,2 e 4,0 dS m-1) e quatro concentrações de ácido salicílico - AS (0; 1,2; 2,4 e 3,6 mM), com três repetições. A aplicação foliar do AS entre as concentrações de 1,2 e 1,6 mM amenizou os efeitos do estresse salino sobre a condutância estomática, a taxa de assimilação de $\mathrm{CO}_{2}$, a transpiração e a eficiência instantânea da carboxilação da gravioleira aos 480 dias após o transplantio. A pulverização com AS com concentrações entre 1,3 e 1,6 mM induziu a aclimatação ao estresse salino na gravioleira, visto que, as plantas tiveram a porcentagem de extravasamento de eletrólitos reduzidos e o crescimento beneficiado pela aplicação de AS, mesmo quando expostas a salinidade. A irrigação com CEa acima de $0,8 \mathrm{dS} \mathrm{m}^{-1}$ reduziu o teor relativo de água nas folhas da gravioleira cv. Morada Nova.
\end{abstract}

Termos para indexação: Annona muricata L; salinidade; estresse abiótico; elicitor.

\section{INTRODUCTION}

Salinity is one of the worst abiotic stresses that threaten agricultural production in the $21^{\text {st }}$ century, and its adverse effects are expected to increase due to the climate change in recent years, especially in semi-arid regions (Ahmadi; Souri, 2018; Souana et al., 2020).

The difficulty for the expansion of crops irrigated with saline water is related to the damage caused by the combination of osmotic and ionic stresses, which restricts the absorption of water and nutrients and consequently, affects physiological processes and plant growth (Ahmadi; Souri, 2020). Salt stress also causes oxidative stress due to the imbalance between the production of reactive oxygen species (ROS) and their detoxification by enzymatic and non-enzymatic reactions (Mohamed et al., 2020).

Given the increasing need to use saline water in irrigated agriculture, studies that enable the use of these 
sources of water have become indispensable. In this context, the use of salicylic acid - SA has emerged to minimize the harmful effects caused by abiotic stresses such as salinity (Nazar et al., 2015).

Salicylic acid is a natural phenolic compound, which is involved in plant growth and physiological processes such as floral induction, stomatal opening and closure, ion absorption, photosynthesis and transpiration (Silva et al., 2020). The beneficial effect of SA on different plant species under salt stress may arise from its role in intensifying the activity of antioxidant enzymes and in protecting membranes against damage (Esan et al., 2017). Souri and Tohidloo (2019) has shown recently that the time and the method of application as well as the concentration of SA can significantly influence plant responses under salinity.

It has been reported that foliar spraying with SA can mitigate the deleterious effects caused by salt stress on strawberry (Samadi; Habibi; Varziri, 2019), almond (Mohammadi et al., 2020), grapes (Ekbic; Ozican; Erdem, 2020), dates (Jasim; Ati, 2020) and orange (Mahmoud et al., 2021). However, information on its use in the soursop crop irrigated with saline waters is scarce.

Soursop (Annona muricata L.) is one of the most important fruit species of the Annonaceae family (Sánchez et al., 2018). Its fruits are appreciated for their succulence, sweet and sub-acid flavor, as well as the pleasant and distinct aroma; its consumption, either fresh or processed, has increased due to its nutritional value and different forms of use in human food (Freitas et al., 2013; Jimenez et al., 2014; Leite Neta et al., 2019). Apart from the medicinal properties of its leaves, fruits, seeds, and roots (Moghadamtousi et al., 2015).

In view of the above, the aim of this study was to evaluate the effects of foliar spraying with salicylic acid on the mitigation of salt stress and on the morphophysiology of soursop cv. Morada Nova.

\section{MATERIAL AND METHODS}

The experiment was carried out from June 2019 to October 2020, in a protected environment (greenhouse), belonging to the Academic Unit of Agricultural Engineering - UAEA of the Federal University of Campina Grande UFCG, located in Campina Grande, Paraíba, Brazil, at the geographical coordinates $7^{\circ} 15^{\prime} 18^{\prime}$ "South latitude, $35^{\circ} 52^{\prime} 28^{\prime \prime}$ 'West longitude and mean altitude of $550 \mathrm{~m}$. Data of temperature (maximum and minimum) and mean relative air humidity during the experimental period are shown in Figure 1.

The treatments consisted of five levels of electrical conductivity of irrigation water - ECw (0.8- control; 1.6 , 2.4,3.2 and $\left.4.0 \mathrm{dS} \mathrm{m}^{-1}\right)$ and four concentrations of salicylic acid - SA $(0 ; 1.2,2.4$ and $3.6 \mathrm{mM})$, in a $5 \times 4$ factorial arrangement, distributed in randomized blocks, with three replicates, totaling 60 experimental units.

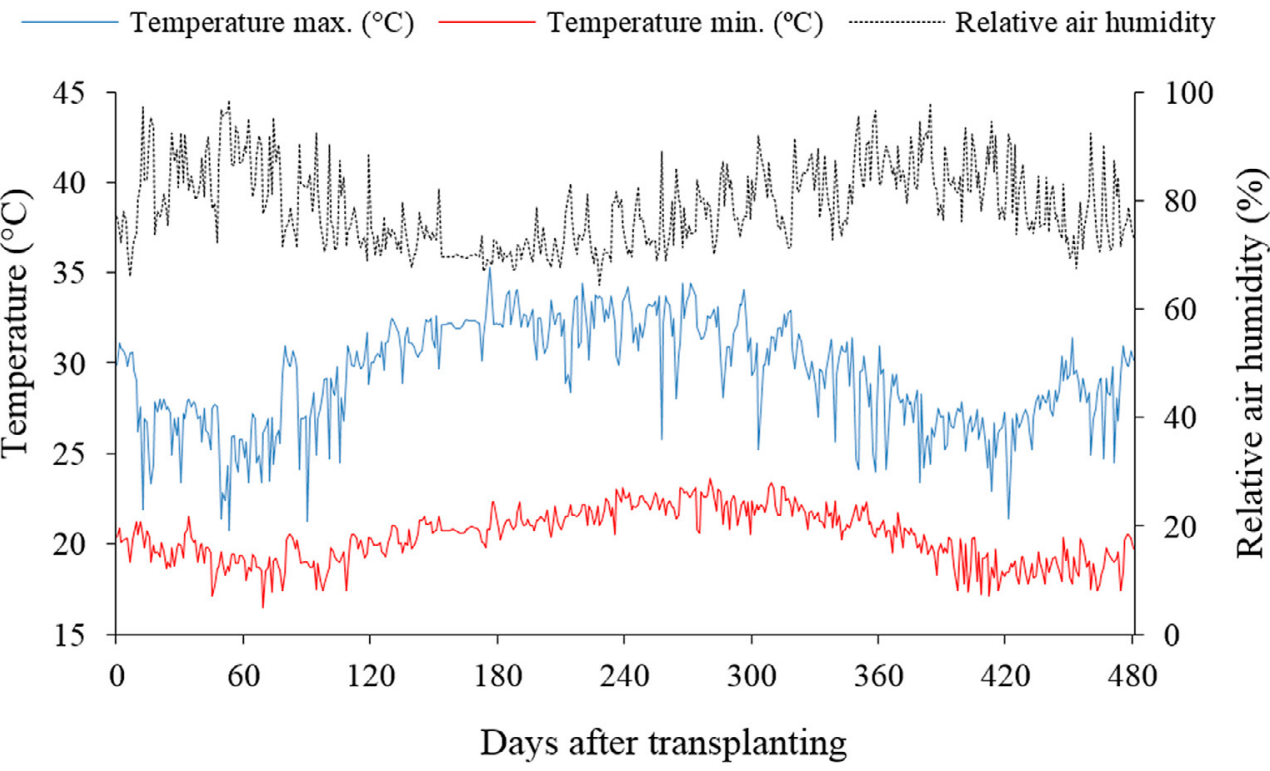

Figure 1: Air temperature (maximum and minimum) and mean relative air humidity observed in the internal area of the greenhouse during the experimental period. 
Salicylic acid concentrations studied were based on a study conducted by Abbaszadeh et al. (2020) and ECw levels were according to results reported by Veloso et al. (2019).

The soursop cultivar 'Morada Nova' was chosen because it is the most appreciated by producers, making up most commercial orchards in Brazil, besides having larger fruits, which can weigh up to $15 \mathrm{~kg}$, and higher production compared to other cultivars (São Jose et al., 2014). The seedlings were propagated sexually and their formation period was 330 days. After this period, they were transplanted to plastic pots of 120 -L capacity.

The experiment was conducted adopting plastic containers as drainage lysimeters, filled with a 1.0-kg layer of crushed stone followed by $160 \mathrm{~kg}$ of soil classified as Entisol (United States, 2014), of 0-0.30 m depth, from the municipality of Lagoa Seca-PB, whose physico-chemical characteristics (Table 1) were determined according to Teixeira et al. (2017).

The irrigation waters with different levels of electrical conductivity were prepared by dissolving $\mathrm{NaCl}, \mathrm{CaCl}_{2} \cdot 2 \mathrm{H}_{2} \mathrm{O}$ and $\mathrm{MgCl}_{2} \cdot 6 \mathrm{H}_{2} \mathrm{O}$ salts, in the equivalent proportion of $7: 2: 1$, respectively, in water from the local supply system $(\mathrm{ECW}=$ $\left.0.38 \mathrm{dS} \mathrm{m}^{-1}\right)$. This proportion is commonly found in sources of water used for irrigation in the Northeast region (Medeiros et al., 2003). The irrigation waters were prepared considering the relationship between $\mathrm{ECW}$ and salt concentration (Richards, 1954), according to Equation 1:

$\mathrm{Q}\left(\mathrm{mmol}_{\mathrm{c}} \mathrm{L}^{-1}\right)=10 \times \mathrm{ECw}\left(\mathrm{dS} \mathrm{m} \mathrm{m}^{-1}\right)$

Where:

$\mathrm{Q}$ - amount of salts to be added $\left(\mathrm{mmol}_{\mathrm{c}} \mathrm{L}^{-1}\right)$

$\mathrm{ECW}$ - electrical conductivity of water $\left(\mathrm{dS} \mathrm{m}^{-1}\right)$
At 75 days after transplanting (DAT), irrigation with saline water began, adopting an interval of 3 days and applying water in each lysimeter according to the treatments, in order to maintain soil moisture close to field capacity. The volume of water to be applied was determined according to the water requirement of the plants, estimated by water balance, and was given by Equation 2:

$\mathrm{VI}=\frac{(\mathrm{Va}-\mathrm{Vd})}{(1-\mathrm{LF})}$

Where:

VI - volume of water to be used in the irrigation event $(\mathrm{mL})$; Va - volume applied in the previous irrigation event $(\mathrm{mL})$; $\mathrm{Vd}$ - volume drained $(\mathrm{mL})$;

LF - leaching fraction of 0.15 , applied every 30 days to avoid excessive accumulation of salts.

The concentrations of SA were obtained by dissolving the product in 30\% ethyl alcohol $(95.5 \%)$, as it is a substance of low solubility in water at room temperature. To reduce the surface tension of the drops on the leaf surface, the adjuvant Wil fix $\left(0.5 \mathrm{~mL} \mathrm{~L}^{-1}\right)$ was used in the preparation of the solution.

Foliar applications began at 60 DAT, on the abaxial and adaxial sides of the leaves. Subsequent applications were performed at 30-day intervals using a backpack sprayer between 17:00 and 17:45 h. The sprayer used is a model from Jacto - Jacto XP with capacity of $12 \mathrm{~L}$, working pressure (maximum) of $88 \mathrm{psi}(6 \mathrm{bar})$ and JD 12P nozzle, and the mean volume applied per plant was $400 \mathrm{~mL}$.

Table 1: Chemical and physical attributes of the soil, in the $0-0.30 \mathrm{~m}$ depth, used in the experiment, before the application of the treatments.

\begin{tabular}{|c|c|c|c|c|c|c|c|c|c|}
\hline \multicolumn{10}{|c|}{ Chemical characteristics } \\
\hline \multirow{2}{*}{$\begin{array}{c}\mathrm{pH}\left(\mathrm{H}_{2} \mathrm{O}\right) \\
(1: 2.5)\end{array}$} & \multirow{2}{*}{$\begin{array}{c}\text { OM } \\
\left(\text { dag kg-1 }^{-1}\right)\end{array}$} & \multirow{2}{*}{$\begin{array}{c}\mathrm{P} \\
\left(\mathrm{mg} \mathrm{kg}^{-1}\right)\end{array}$} & $\mathrm{K}^{+}$ & $\mathrm{Na}^{+}$ & $\mathrm{Ca}{ }^{2+}$ & $\mathrm{Mg}^{2+}$ & $\mathrm{Al}^{3+}+\mathrm{H}^{-}$ & \multirow{2}{*}{$\begin{array}{l}\text { ESP } \\
(\%)\end{array}$} & \multirow{2}{*}{ 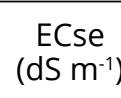 } \\
\hline & & & \multicolumn{5}{|c|}{ - } & & \\
\hline 5.90 & 1.36 & 6.80 & 8.60 & 3.68 & 52.0 & 44.48 & 1.93 & 1.87 & 1.0 \\
\hline \multicolumn{10}{|c|}{ Physical characteristics } \\
\hline \multicolumn{3}{|c|}{ Size fraction $\left(\mathrm{g} \mathrm{kg}^{-1}\right)$} & & \multicolumn{2}{|c|}{ Water content $(\mathrm{kPa})$} & \multirow{3}{*}{$\begin{array}{c}\text { AW } \\
\left(\text { dag kg-1) }^{-1}\right)\end{array}$} & \multirow{3}{*}{$\begin{array}{l}\text { Total } \\
\text { porosity } \\
(\%)\end{array}$} & \multirow{2}{*}{$\mathrm{BD}$} & \multirow{2}{*}{ PD } \\
\hline \multirow{2}{*}{ Sand } & \multirow{2}{*}{ Silt } & \multirow{2}{*}{ Clay } & Textural & $33.42^{*}$ & $1519.5^{* *}$ & & & & \\
\hline & & & & \multicolumn{2}{|c|}{ 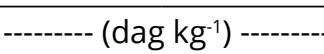 } & & & \multicolumn{2}{|c|}{---- $\left(\mathrm{kg} \mathrm{dm}^{-1}\right)$---. } \\
\hline 732.9 & 142.1 & 125.0 & SL & 11.98 & 4.32 & 7.66 & 47.74 & 1.39 & 2.66 \\
\hline
\end{tabular}

$\mathrm{OM}$ - Organic Matter: Walkley-Black Wet Digestion; $\mathrm{Ca}^{2+}$ and $\mathrm{Mg}^{2+}$ extracted with $1 \mathrm{M} \mathrm{KCl}$ at pH 7.0; $\mathrm{Na}^{+}$and $\mathrm{K}^{+}$extracted with 1 $\mathrm{M} \mathrm{NH}_{4} \mathrm{OAc}$ at $\mathrm{pH} 7.0 ; \mathrm{Al}^{3+}$ and $\mathrm{H}^{+}$extracted with $0.5 \mathrm{M} \mathrm{CaOAc}$ at $\mathrm{pH}$ 7.0; ESP - Exchangeable sodium percentage; ECse - Electrical conductivity of saturation extract; SL - Sandy loam; AW - Available water; BD - Bulk density; PD - Particle density; * - Field capacity; ** - Wilting point. 
Fertilization with nitrogen, phosphorus and potassium was based on the recommendations proposed by Cavalcante et al. (2008) for soursop crop, with $100 \mathrm{~g}$ of nitrogen, $60 \mathrm{~g}$ of $\mathrm{P}_{2} \mathrm{O}_{5}$ and $40 \mathrm{~g}$ of $\mathrm{K}_{2} \mathrm{O}$ per plant per year, split into 24 portions and applied at 15-day intervals. Urea, monoammonium phosphate and potassium chloride were used as sources of nitrogen, phosphorus and potassium, respectively.

A Dripsol ${ }^{\circledR}$ Micro solution, at the concentration of $1.0 \mathrm{~g} \mathrm{~L}^{-1}$, was applied every two weeks to meet the micronutrient requirement (composition: $\mathrm{Mg}$ (1.1\%); $\mathrm{Zn}$ (4.2\%); B (0.85\%); $\mathrm{Fe}$ (3.4\%); $\mathrm{Mn}(3.2 \%)$; $\mathrm{Cu}(0.5 \%)$; Mo $(0.05 \%))$, sprayed on the adaxial and abaxial sides of the leaves using a backpack sprayer. During the experiment, cultural practices such as cleaning pruning, weeding, soil scarification and the phytosanitary control recommended for the crop were performed as and when necessary.

At $480 \mathrm{DAT}$, the following parameters were evaluated: relative water content; percentage of intercellular electrolyte leakage (\% IEL); gas exchange - stomatal conductance $(g s)$, transpiration $(E), \mathrm{CO}_{2}$ assimilation rate $(A)$, internal $\mathrm{CO}_{2}$ concentration $(C i)$, instantaneous water use efficiency (WUEi) $(A / E)$ and instantaneous carboxylation efficiency (CEi) $(A / C i)$; and the growth variables - crown height $\left(\mathrm{H}_{\text {Crown }}\right)$, stem diameter $(\mathrm{SD})$, crown diameter $\left(\mathrm{D}_{\text {Crown }}\right)$, crown volume $\left(\mathrm{V}_{\text {Crown }}\right)$ and vegetative vigor index (VVI).

To determine the relative water content (RWC), two leaves were removed from the middle third of the main branch to obtain five discs of $12 \mathrm{~mm}$ of diameter from each leaf. Immediately after collection, the discs were weighed, avoiding moisture loss, obtaining the fresh mass (FM); then, these samples were placed in beaker, immersed in $50 \mathrm{~mL}$ of distilled water and conditioned for 90 minutes. After this period, excess water from the discs was removed with paper towels and the turgid mass (TM) of the samples was obtained, which were then dried in an oven at temperature $\approx 65 \pm 3{ }^{\circ} \mathrm{C}$, until constant weight to obtain the dry mass (DM) of the samples. The RWC was determined according to Lima et al. (2015), by Equation 3:

$$
\mathrm{RWC}=\frac{\mathrm{FM}-\mathrm{DM}}{\mathrm{TM}-\mathrm{MS}} x 100
$$

The percentage of intercellular electrolyte leakage (\% IEL) was determined using a copper hole puncher to obtain five leaf discs with an area of $1.54 \mathrm{~cm}^{2}$ each, per experimental unit, which were washed and placed in Erlenmeyer ${ }^{\circledR}$ flask containing $50 \mathrm{~mL}$ of distilled water. After being closed with aluminum foil, the Erlenmeyer ${ }^{\mathrm{B}}$ flasks were kept at temperature of $25^{\circ} \mathrm{C}$ for 90 minutes and then the initial electrical conductivity of the medium (Xi) was measured using a benchtop conductivity meter (MB11, MS Techonopon $\left.^{\circledR}\right)$. Then, the Erlenmeyer ${ }^{\circledR}$ flasks were subjected to a temperature of $90{ }^{\circ} \mathrm{C}$ for 90 minutes in a drying oven $\left(\mathrm{SL} 100 / 336, \mathrm{SOLAB}^{\circledR}\right)$ and, after cooling of their contents, the final conductivity (Xf) was measured. The percentage of intercellular electrolyte leakage was expressed as the percentage of initial electrical conductivity relative to the electrical conductivity after treatment for 90 minutes at 90 ${ }^{\circ} \mathrm{C}:[(\mathrm{Xi} / \mathrm{Xf}) \mathrm{x} 100]$ (Scotti-Campos et al., 2013).

Gas exchange was measured on the third leaf, counted from the apex of the main branch of the plant, using irradiation of $1200 \mu \mathrm{mol}$ photons $\mathrm{m}^{-2} \mathrm{~s}^{-1}$ and airflow of $200 \mathrm{~mL} \mathrm{~min}^{-1}$, using the portable photosynthesis meter LCPro+ from ADC BioScientific Ltda.

$\mathrm{H}_{\text {Crown }}$ was measured by taking as reference the distance from the plant collar to the insertion of the apical meristem; SD was measured at $3 \mathrm{~cm}$ height from the plant collar with a digital caliper; $\mathrm{D}_{\text {Crown }}$ was obtained by mean of crown diameter observed in the directions of the planting row (DR) and inter-row (DIR); $\mathrm{V}_{\text {Crown }}$ was calculated from $\mathrm{H}_{\text {Crown? }}$, DR and DIR, using Equation 4; and VVI was obtained using Equation 5, according to Portella et al. (2016).

$\mathrm{V}_{\text {Crown }}=\frac{\pi}{6} \times \mathrm{H}_{\text {Crown }} \times$ DR $\times$ DIR

$\mathrm{VVI}=\frac{\mathrm{H}_{\text {Crown }}+\mathrm{D}_{\text {Crown }}+(\mathrm{SD} \times 10)}{100}$

Where:

$\mathrm{V}_{\text {Crown }}$ - crown volume $\left(\mathrm{m}^{3}\right)$;

$\mathrm{D}_{\text {Crown }}$ - crown diameter $(\mathrm{m})$;

VVI - vegetative vigor index;

$\mathrm{H}_{\text {Crown }}$ - crown height (m);

$\mathrm{DR}$ - crown diameter in the direction of the row (m);

DIR - crown diameter in the direction of the inter-row (m); and,

$\mathrm{SD}$ - stem diameter (mm).

The data were subjected to the distribution normality test (Shapiro-Wilk test) at 0.05 probability level. Subsequent analysis of variance was performed at 0.05 and 0.01 probability level and, in cases of significance, linear and quadratic regression analysis was performed using the statistical program SISVAR-ESAL (Ferreira, 2019). The choice of the model was made based on the significance of the coefficients. In case of significance of the interaction between factors, TableCurve 3D software was used to construct the response surfaces. 


\section{RESULTS AND DISCUSSION}

There was significant interaction $(\mathrm{p}<0.01)$ between salinity levels (SL) and salicylic acid (SA) concentrations only for the percentage of intercellular electrolyte leakage (Table 2). The relative water content (RWC) was significantly affected by both factors individually.

Table 2: Summary of the analysis of variance for relative water content (RWC) and percentage of intercellular electrolyte leakage (\% IEL) of soursop cv. 'Morada Nova' cultivated with saline waters and foliar application of salicylic acid, at 480 days after transplanting.

\begin{tabular}{crrr}
\hline \multirow{2}{*}{ Source of variation } & \multirow{2}{*}{ DF } & \multicolumn{2}{c}{ Mean squares } \\
\cline { 3 - 4 } & & \multicolumn{1}{c}{ RWC } & $\%$ IEL \\
\hline Salinity levels (SL) & 4 & $35.82^{* *}$ & $22.48^{* *}$ \\
Linear regression & 1 & $39.31^{* *}$ & $54.69^{* *}$ \\
Quadratic regression & 1 & $27.55^{\text {ns }}$ & $0.27^{\text {ns }}$ \\
Salicylic acid (SA) & 3 & $90.54^{* *}$ & $82.11^{* *}$ \\
Linear regression & 1 & $89.77^{*}$ & $28.88^{\text {ns }}$ \\
Quadratic regression & 1 & $137.87^{* *}$ & $209.14^{* *}$ \\
Interaction (SL x SA) & 12 & $70.14^{\text {ns }}$ & $23.84^{* *}$ \\
Blocks & 2 & $3.91^{\text {ns }}$ & $3.27^{\text {ns }}$ \\
Residue & 32 & 10.31 & 6.35 \\
CV (\%) & & 6.99 & 8.54 \\
\hline
\end{tabular}

$\mathrm{ns}, *$ and $* *$ respectively not significant, significant at $\mathrm{p}<0.05$ and at $p<0.01$. CV: Coefficient of variation.

The relative water content was reduced linearly with the increase in the electrical conductivity of irrigation water (Figure 2A), by $3.9 \%$ per unit increase in $\mathrm{ECw}$. A reduction of $13.0 \%$ was observed when comparing the RWC of plants irrigated with water of highest salinity $\left(4.0 \mathrm{dS} \mathrm{m}^{-1}\right)$ to that of plants cultivated under the lowest salinity level $\left(0.8 \mathrm{dS} \mathrm{m}^{-1}\right)$. RWC is a variable that indicates the plant's water status, and its reduction as a result of salinity may occur due to osmotic effects, which restricts the absorption of water by plants or due to enhancement in leaf transpiration rates (Morais et al., 2018; Ahmadi; Souri, 2019; Hatamian et al., 2020).

In research conducted by Silva Neta et al. (2021), evaluating the morphophysiology of 'BRS Rubi do Cerrado' passion fruit irrigated with saline water ( 0.3 to 3.5 $\mathrm{dS} \mathrm{m}^{-1}$ ), also observed a reduction in RWC corresponding to $2.91 \%$ per unit increase in electrical conductivity.
Salicylic acid concentrations influenced the RWC of soursop (Figure 2B). Plants subjected to the concentration of $1.45 \mathrm{mM}$ stood out with the highest value of RWC (84.3\%) showing an increase of $8.8 \%$ compared to those grown under control treatment (without SA application). Such a response may be related to the effect of SA on the accumulation of osmolytes, which contribute to the reduction of osmotic potential, ensuring greater water absorption and an increase in the relative water content of tissues (Pooja; Sharma, 2016).

For \% IEL (Figure 2C), it was verified that the SA concentration of $1.3 \mathrm{mM}$ mitigated the adverse effects of salinity, with the lowest \% IEL value $(25.78 \%)$ obtained in plants irrigated with $0.8 \mathrm{dS} \mathrm{m}^{-1}$ water. On the other hand, the plants in the control treatment (0 mM SA) when irrigated with $0.8 \mathrm{dS} \mathrm{m}^{-1}$ water showed \% IEL of $27.43 \%$, that is, an increase of $6.4 \%$ in comparison to plants subjected to a concentration of $1.3 \mathrm{mM}$.

The positive effects of SA in reducing percentage of intercellular electrolyte leakage of soursop can be attributed to the improvement in nutrient absorption, membrane protection and increase in photosynthetic activity. In addition, SA can interact with signaling pathways of reactive oxygen species (ROS) and reduce oxidative stress (HerreraVásquez; Salinas; Holuigue, 2015; Batista et al., 2019).

It is worth mentioning that the increase in the electrical conductivity of irrigation water associated with SA concentrations greater than $1.3 \mathrm{mM}$ intensified the deleterious effects of salinity on the percentage of intercellular electrolyte leakage, with the highest \% IEL (34.79\%) obtained in plants irrigated with $4.0 \mathrm{dS} \mathrm{m}^{-1}$ water and under SA concentration of $3.6 \mathrm{mM}$.

This response can be explained by the fact that salt stress induces the production of ROS, due to the reduction of light absorption and the electron transport chain, causing photooxidative damage to photosystems (Yudina et al., 2020), peroxidation of the cell membrane and increased percentage of intercellular electrolyte leakage.

According to the summary of the analysis of variance (Table 3 ), the interaction between SL and SA concentrations significantly influenced all gas exchange variables analyzed, except for the internal $\mathrm{CO}_{2}$ concentration and instantaneous water use efficiency. Salinity levels, on the other hand, significantly $(\mathrm{p}<0.01)$ affected the parameters $C i, g_{s}, E, A$ and $C E i$. Salicylic acid concentrations caused significant effects on $g s, A, C E i$ and $W U E i$. Besides this, significant effect of blocks was also observed on $C i, g s, A, C E i$ and $W U E i$, provoked perhaps due to differences in lumonisidade and temperature in the relatively large size $(20 \times 28 \mathrm{~m})$ of greenhouse. 

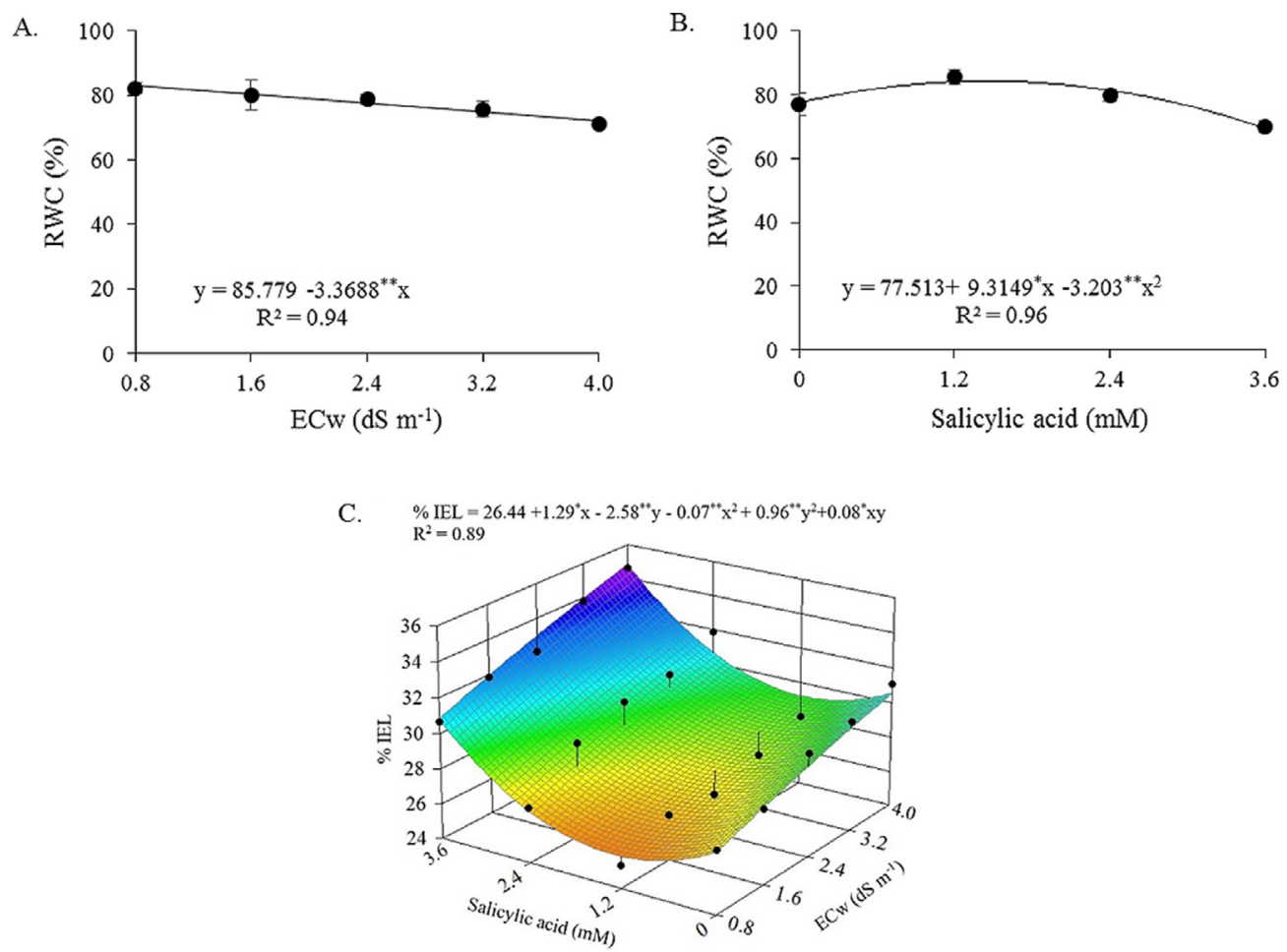

Figure 2: Relative water content - RWC of soursop cv. 'Morada Nova' as a function of the electrical conductivity of irrigation water - ECW (A) and concentrations of salicylic acid - SA (B); and response surface for the percentage of intercellular electrolyte leakage - \% IEL (C) as a function of the interaction between ECW and concentrations of SA, at 480 days after transplanting.

$X$ and $Y-E C W$ and SA concentration, respectively; ${ }^{*, * *}$ Significant at $p \leq 0.05$ and at $p \leq 0.01$, respectively. The point and vertical lines represent Mean +/- Standard Error $(n=3)$.

Table 3: Summary of the analysis of variance for the internal $\mathrm{CO}_{2}$ concentration (Ci), stomatal conductance (gs), transpiration $(E), \mathrm{CO}_{2}$ assimilation rate $(A)$, instantaneous carboxylation efficiency $(C E i)$ and instantaneous water use efficiency (WUEi) of soursop cv. 'Morada Nova' irrigated with saline waters and under foliar application of salicylic acid, at 480 days after transplanting.

\begin{tabular}{|c|c|c|c|c|c|c|c|}
\hline \multirow[t]{2}{*}{ Source of variation } & \multirow[t]{2}{*}{ DF } & \multicolumn{6}{|c|}{ Mean squares } \\
\hline & & $\mathrm{Ci}$ & gs & $\mathrm{E}$ & $\mathrm{A}$ & CEi & WUEi \\
\hline Salinity levels (SL) & 4 & $1796.9^{\star}$ & $2.4 \times 10^{-3 * \star}$ & $0.98^{* *}$ & $16.57^{* \star}$ & $5.9 \times 10^{-4^{* \star}}$ & $0.54^{\mathrm{ns}}$ \\
\hline Linear regression & 1 & $6393.5^{* *}$ & $4.8 \times 10^{-3 * *}$ & $3.02^{* *}$ & $61.76^{* *}$ & $2.2 \times 10^{-3 * *}$ & $1.81^{\mathrm{ns}}$ \\
\hline Quadratic regression & 1 & $6.86^{\mathrm{ns}}$ & $3.6 \times 10^{-3^{*}}$ & $0.38^{\text {ns }}$ & $0.13^{\text {ns }}$ & $1.5 \times 10^{-5 n s}$ & $0.15^{\mathrm{ns}}$ \\
\hline Salicylic acid (SA) & 3 & $1166.6^{\mathrm{ns}}$ & $5.9 \times 10^{-4^{*}}$ & $0.22^{\text {ns }}$ & $3.71^{*}$ & $1.9 \times 10^{-4 * *}$ & $0.77^{\star \star}$ \\
\hline Linear regression & 1 & $87.5^{\text {ns }}$ & $1.2 \times 10^{-3^{*}}$ & $0.54^{\mathrm{ns}}$ & $4.76^{*}$ & $9.7 \times 10^{-5 n s}$ & $0.02 \mathrm{~ns}$ \\
\hline Quadratic regression & 1 & $194.5^{\mathrm{ns}}$ & $6.0 \times 10^{-4 \mathrm{~ns}}$ & $0.05^{\text {ns }}$ & $6.29^{* *}$ & $4.9 \times 10^{-4 * *}$ & $1.32^{*}$ \\
\hline Interaction (SL x SA) & 12 & $1069.1^{\text {ns }}$ & $2.4 \times 10^{-3 * *}$ & $0.42^{* *}$ & $3.22^{* \star}$ & $1.2 \times 10^{-4^{* *}}$ & $0.43^{\text {ns }}$ \\
\hline Blocks & 2 & $5590.4^{*}$ & $1.5 \times 10^{-3 * *}$ & $0.26^{\mathrm{ns}}$ & $9.14^{* *}$ & $5.5 \times 10^{-5 n s}$ & $3.08^{* *}$ \\
\hline Residue & 32 & 685.2 & $1.8 \times 10^{-4}$ & 0.11 & 1.08 & $3.8 \times 10^{-5}$ & 0.26 \\
\hline CV (\%) & & 17.80 & 12.74 & 17.74 & 16.68 & 20.17 & 15.18 \\
\hline
\end{tabular}

$n s, *, \star *$ respectively not significant, significant at $0<0.05$ and at $p<0.01$. CV: Coefficient of variation. 
The increase in the $\mathrm{ECw}$ caused a positive linear effect on the internal $\mathrm{CO}_{2}$ concentration (Figure 3), with an increment of $5.1 \%$ per unit increase in ECw. Plants irrigated with water of highest salinity $\left(4.0 \mathrm{dS} \mathrm{m}^{-1}\right)$ had an increase of $15.7 \%\left(30.4 \mu \mathrm{mol} \mathrm{m} \mathrm{m}^{-2} \mathrm{~s}^{-1}\right)$, compared to those cultivated under ECw of $0.8 \mathrm{dS} \mathrm{m}^{-1}$. The increase in the internal concentration in the substomatic chamber in plants grown under salt stress is indicative of deterioration of the photosynthetic apparatus, as the damage caused to the structures responsible for $\mathrm{CO}_{2}$ fixation is not only due to stomatal factors, but also to the accumulation of salts in the leaves (Hussain et al., 2012). The increase in the internal concentration of $\mathrm{CO}_{2}$ due to the increase in salinity was also observed in other crops, such as West Indian cherry (Dias et al., 2018), passion fruit (Lima et al., 2020) and pomegranate (Soares et al., 2021).

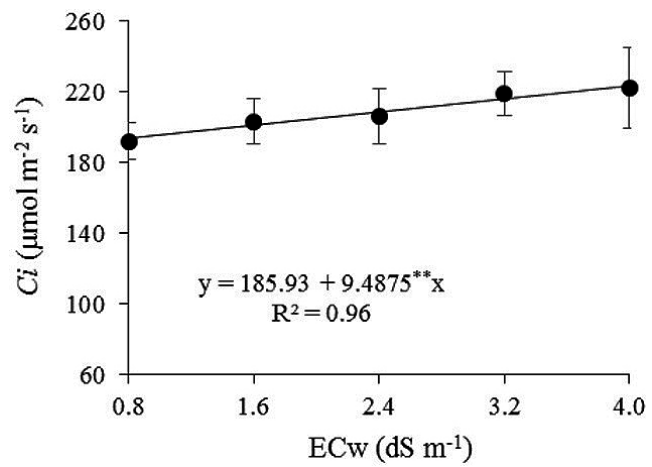

Figure 3: Internal $\mathrm{CO}_{2}$ concentration - $\mathrm{Ci}$ of soursop cV. 'Morada Nova' as a function of the electrical conductivity of irrigation water - ECW, at 480 days after transplanting.

${ }^{*}$ Significant at $p \leq 0.01$. The point and vertical lines represent Mean +/- Standard Error $(n=3)$.

Soursop plants irrigated with water of $1.4 \mathrm{dS} \mathrm{m}^{-1}$ and subjected to a SA concentration of $1.2 \mathrm{mM}$ obtained the highest value of $g s\left(0.083 \mathrm{~mol} \mathrm{H}_{2} \mathrm{O} \mathrm{m}^{-2} \mathrm{~s}^{-1}\right)$ (Figure 4A), which corresponded to an increase of $5.2 \%\left(0.004 \mathrm{~mol} \mathrm{H}_{2} \mathrm{O}\right.$ $\left.\mathrm{m}^{-2} \mathrm{~s}^{-1}\right)$ in comparison to plants under control treatment $(0$ $\mathrm{mM}$ ) irrigated using water with the same salinity level. However, SA concentrations above $1.2 \mathrm{mM}$ associated with the increase in $\mathrm{ECw}$ led to a reduction in $g s$, with the lowest value $\left(0.031 \mathrm{~mol} \mathrm{H}_{2} \mathrm{O} \mathrm{m}^{-2} \mathrm{~s}^{-1}\right)$ being obtained in plants subjected to SA concentration of $3.6 \mathrm{mM}$ and irrigated with water of $4.0 \mathrm{dS} \mathrm{m}^{-1}$.

Under conditions of salt stress, plants can close their stomata in response to the decrease in the relative water content in the leaves (Figure 2A) due to the osmotic effect. Under stress conditions, the reduction of $g s$ is a defense mechanism of the plant to minimize the loss of water by the leaves to the atmosphere and, consequently, the absorption of water and salts from the soil solution (Hussain et al., 2012). Despite the reduction of stomatal conductance in plants under the highest salinity level $\left(4.0 \mathrm{dS} \mathrm{m}^{-1}\right)$, there was no restriction on the internal $\mathrm{CO}_{2}$ concentration (Figure 3).

In a study conducted by Khoshbakht and Asgharei (2015), evaluating the influence of SA (0 to $1 \mathrm{mM}$ ) applied through the leaves on the growth, gas exchange and chlorophyll fluorescence of citrus under saline conditions ( 0 to $75 \mathrm{mM}$ of $\mathrm{NaCl}$ ), it was verified that the application of SA at the concentration of $1.0 \mathrm{mM}$ promoted a higher degree of stomatal opening compared to the control treatment.

Salicylic acid at concentrations of up to 1.4 $\mathrm{mM}$ promoted an increase in $E$ and $A$, regardless of the electrical conductivity of irrigation water (Figure 4B and $4 \mathrm{C}$ ). It was observed that plants subjected to SA concentration of $1.4 \mathrm{mM}$ and irrigated with water of $1.6 \mathrm{dS} \mathrm{m}^{-1}$ obtained higher values of $E\left(2.17 \mathrm{mmol} \mathrm{H}_{2} \mathrm{O}\right.$ $\left.\mathrm{m}^{-2} \mathrm{~s}^{-1}\right)$ and $A\left(7.7 \mathrm{mmol} \mathrm{CO}_{2} \mathrm{~m}^{-2} \mathrm{~s}^{-1}\right)$. Soursop plants irrigated with water of $1.6 \mathrm{dS} \mathrm{m}^{-1}$ and subjected to SA concentration of $1.4 \mathrm{mM}$ increased by $7.8 \%(0.16 \mathrm{mmol}$ $\left.\mathrm{H}_{2} \mathrm{O} \mathrm{m}^{-2} \mathrm{~s}^{-1}\right)$ and $6.8 \%\left(0.49 \mathrm{mmol} \mathrm{CO}_{2} \mathrm{~m}^{-2} \mathrm{~s}^{-1}\right)$ their $E$ and $A$, respectively, compared to those cultivated under $\mathrm{ECw}$ of $1.6 \mathrm{dS} \mathrm{m}^{-1}$ and without application of SA $(0 \mathrm{mM})$.

Similar results were obtained by Mohammadi et al. (2020), evaluating the effect of foliar spraying of SA (0 to $2 \mathrm{mM}$ ) on almond plants (Prunus amygdalus L.) under salt stress $\left(0\right.$ to $\left.8 \mathrm{dS} \mathrm{m}^{-1}\right)$; these authors observed that the application of SA at concentration of $1 \mathrm{mM}$ mitigated the deleterious effects of salinity on the stomatal conductance, transpiration and $\mathrm{CO}_{2}$ assimilation rate of plants.

Salicylic acid helps in the protection and increase in the activity of antioxidant enzymes under stressful conditions, making plants tolerant to stress (Rajeshwari; Bhuvaneshwari, 2017). Under conditions of salt stress, SA can cause decrease of $\mathrm{Na}^{+}$and $\mathrm{Cl}^{-}$ions and increase of the $\mathrm{K}^{+} / \mathrm{Na}^{+}$ratio, improving photosynthetic activity (Gunes et al., 2007; Tufail et al., 2013). According to Nahar et al. (2016), the substitution of $\mathrm{Na}^{+}$by $\mathrm{K}^{+}$, exclusion of $\mathrm{Na}^{+}$and retention of intracellular $\mathrm{K}^{+}$are important mechanisms for plant tolerance to salt stress.

For $C E i$ (Figure 4D), it was verified that SA concentrations $1.6 \mathrm{mM}$ and irrigation water salinity from $1.3 \mathrm{dS} \mathrm{m}^{-1}$ had a negative influence, with the lowest value of $C E i\left(0.017\left(\mu \mathrm{mol} \mathrm{m} \mathrm{m}^{-2} \mathrm{~s}^{-1}\right)\left(\mu \mathrm{mol} \mathrm{mol}{ }^{-1}\right)^{-1}\right)$ obtained in plants irrigated with water of $4.0 \mathrm{dS} \mathrm{m}^{-1}$ and under SA concentration of $3.6 \mathrm{mM}$. 

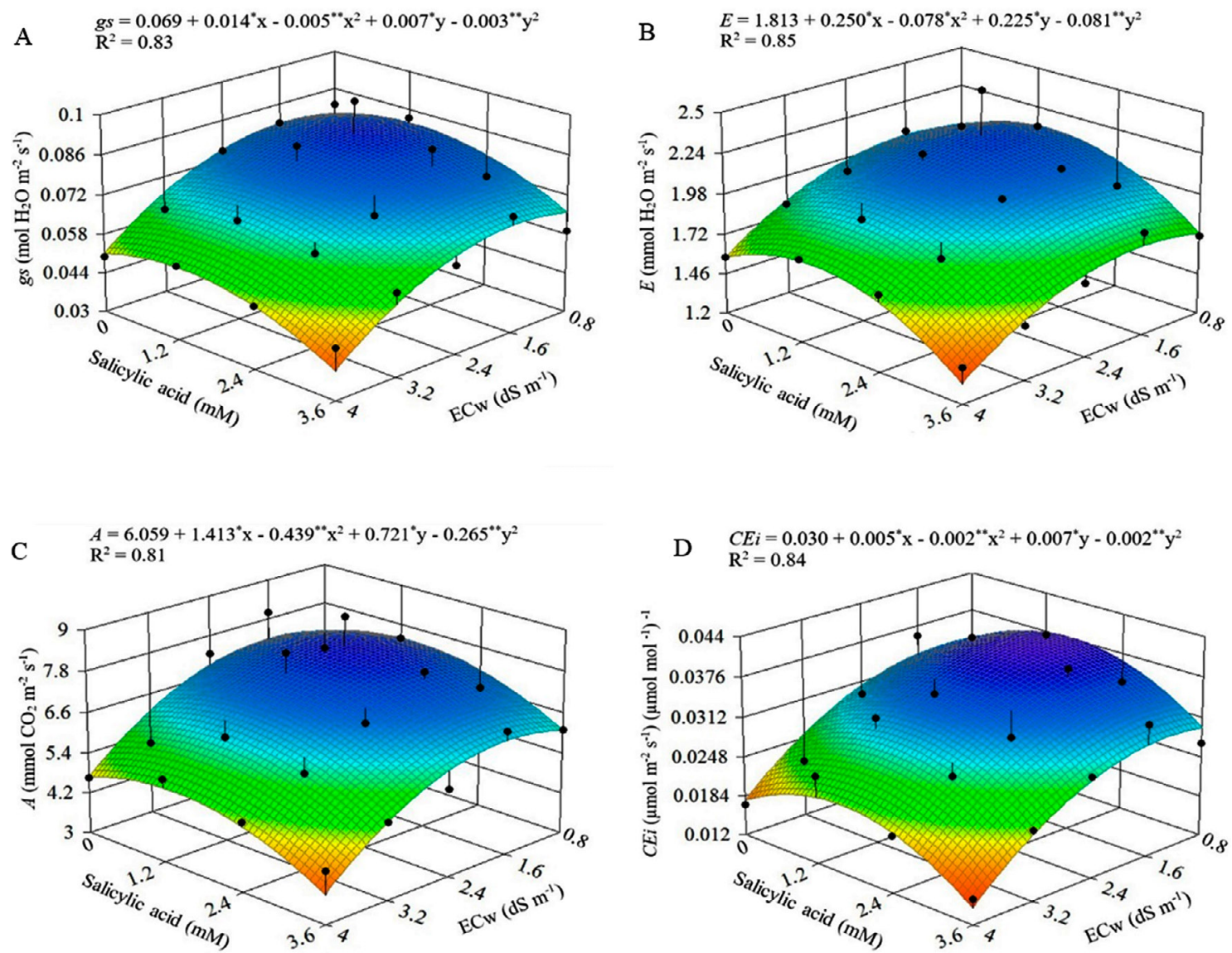

Figure 4: Response surface for stomatal conductance - $g s(\mathrm{~A})$, transpiration - $E(\mathrm{~B}), \mathrm{CO}_{2}$ assimilation rate - $A(\mathrm{C})$ and instantaneous carboxylation efficiency - CEi (D) of soursop cv. Morada Nova as a function of the interaction between the electrical conductivity of irrigation water - ECW and the concentrations of salicylic acid, at 480 days after transplanting.

$X$ and $Y-E C W$ and SA concentration, respectively; ${ }^{*, * *}$ Significant at $p \leq 0.05$ and at $p \leq 0.01$, respectively.

The reductions in CEi are related to decreases in $\mathrm{CO}_{2}$ assimilation rate (Figure $4 \mathrm{C}$ ) and increase in $\mathrm{Ci}$ (Figure 3), due to the low efficiency of the RuBisCO enzyme in $\mathrm{CO}_{2}$ carboxylation (Sousa et al., 2016). It clearly indicates that salinity may have increased mesophilic resistance to the entry of atmospheric $\mathrm{CO}_{2}$ into carboxylation sites and/or reduced enzymatic activity associated with photosynthetic carbon metabolism, this effect being common in plants grown under saline conditions (Soares et al., 2021).

Salicylic acid concentrations significantly influenced the instantaneous water use efficiency of soursop (Figure 5). It is observed that plants subjected to SA concentration of $1.32 \mathrm{mM}$ stood out with higher $W U E i\left[3.47\left(\mu \mathrm{mol} \mathrm{m}^{-2} \mathrm{~s}^{-1}\right)\left(\mu \mathrm{mol} \mathrm{mol}^{-1}\right)^{-1}\right]$, with a reduction in $W U E i$ when sprayed with SA concentrations above
$1.32 \mathrm{mM}$. An increase of $6.6 \%\left[0.21\left(\mu \mathrm{mol} \mathrm{m}{ }^{-2} \mathrm{~s}^{-1}\right)(\mu \mathrm{mol}\right.$ $\left.\mathrm{mol}^{-1}\right)^{-1}$ ] was found when comparing the WUEi of plants subjected to SA concentration of $1.32 \mathrm{mM}$ to that of plants treated with SA concentration of $0 \mathrm{mM}$.

Salicylic acid caused increments in RWC (Figure 1B) and WUEi (Figure 5), and mitigated the effects of salt stress on the percentage of intercellular electrolyte leakage (Figure 2C). Plants sprayed with SA at concentrations between 1.2 and $1.6 \mathrm{mM}$ and subjected to salt stress showed higher values of $g_{s}, E, A$ and $C E i$ (Figures 4) compared to those cultivated without application of SA.

There was a significant effect of the interaction between salinity levels and SA concentrations on all growth variables, except on crown diameter (Table 4). Stem diameter, crown height, crown volume and vegetative 
vigor index were significantly $(\mathrm{p}<0.01)$ affected by salinity levels. On the other hand, salicylic acid concentrations significantly affected only crown height and volume. Besides this, the effect of block was significant on stem diameter and vegetative vigor index due to the reasons explained earlier.

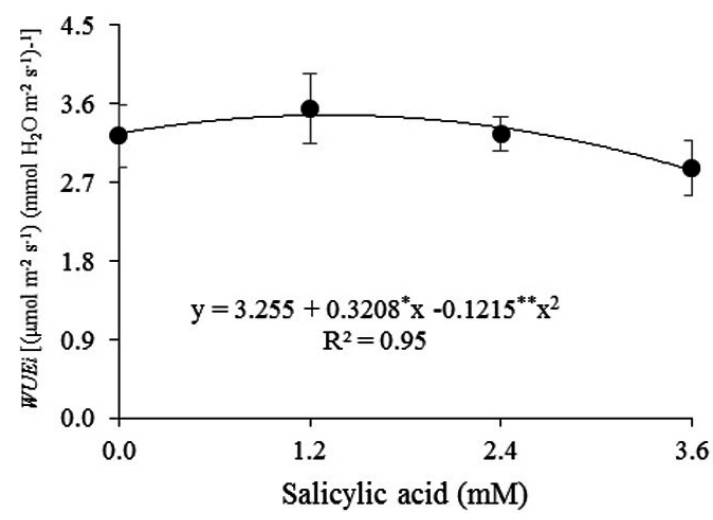

Figure 5: Instantaneous water use efficiency - WUEi of soursop cv. Morada Nova as a function of salicylic acid concentrations - SA, at 480 days after transplanting.

*** Significant at $p \leq 0.05$ and $p \leq 0.01$, respectively. The point and vertical lines represent Mean $+/$ - Standard Error $(n=3)$.

Spraying with SA up to a concentration of 1.6 $\mathrm{mM}$ promoted an increase in $\mathrm{SD}, \mathrm{H}_{\text {Crown }}, \mathrm{V}_{\text {Crown }}$ and VVI of soursop, regardless of the electrical conductivity of irrigation water (Figure 6A, 6B, 6C and 6D). It was observed that plants subjected to SA concentration of 1.6 $\mathrm{mM}$ and irrigated with water of $1.7 \mathrm{dS} \mathrm{m}^{-1}$ obtained higher values of $\mathrm{SD}(36.54 \mathrm{~mm}), \mathrm{H}_{\text {Crown }}(1.89 \mathrm{~m}), \mathrm{V}_{\text {Crown }}(1.25$ $\mathrm{m}^{3}$ ) and VVI (3.19). When comparing in relative terms the $\mathrm{SD}, \mathrm{H}_{\text {Crown }}, \mathrm{V}_{\text {Crown }}$ and VVI of plants irrigated with water of $1.7 \mathrm{dS} \mathrm{m}^{-1}$ and subjected to SA concentration of $1.6 \mathrm{mM}$ to the values of plants cultivated with the same salinity level $\left(1.7 \mathrm{dS} \mathrm{m}^{-1}\right)$, but without the application of SA $(0 \mathrm{mM})$, there were increments of respectively, $4.84 \%(1.69 \mathrm{~mm}), 4.98 \%(0.09 \mathrm{~m}), 9.81 \%\left(0.11 \mathrm{~m}^{3}\right)$ and $7.27 \%(0.55)$.

Nowadays, soil and water salinity are continuously increasing due to climate change, global warming and human activities including intensive cultivation and application of chemical fertilizers (Hatamian et al., 2019; Souri; Bakhtiarizade, 2019). Different organic and inorganic compounds have shown to reduce the adverse effects of environmental constrains such as salinity (Souri; Hatamian, 2019; Ahmadi; Souri, 2018). In this context, salicylic acid plays an important role in the regulation of various physiological processes and plant development, besides increasing root cell growth through the division and expansion of the meristem, thus contributing to plant growth and development (Boukraâ et al., 2013; Souri; Tohidloo, 2019). Moreover, the beneficial effect of SA on gas exchange variables results improvement in growth parameters, as observed in the present study.

Table 4: Summary of the analysis of variance for stem diameter (SD), crown height $\left(\mathrm{H}_{\text {crown }}\right)$, crown diameter $\left(\mathrm{D}_{\text {crown }}\right)$, crown volume $\left(\mathrm{V}_{\text {crown }}\right)$ and vegetative vigor index $(\mathrm{VVI})$ of soursop irrigated with saline water and under foliar application of salicylic acid, at 480 days after transplanting.

\begin{tabular}{|c|c|c|c|c|c|c|}
\hline \multirow{2}{*}{ Source of variation } & \multirow{2}{*}{ DF } & \multicolumn{5}{|c|}{ Mean squares } \\
\hline & & SD & $\mathrm{H}_{\text {Crown }}$ & $\mathrm{D}_{\text {Crown }}$ & $\mathrm{V}_{\text {Crown }}$ & VVI \\
\hline Salinity levels (SL) & 4 & $80.91^{* *}$ & $0.087^{\star \star}$ & $0.05^{\text {ns }}$ & $0.23^{* *}$ & $0.81^{* *}$ \\
\hline Linear regression & 1 & $299.16^{\star *}$ & $0.15^{\star \star}$ & $0.14^{\mathrm{ns}}$ & $0.51^{* *}$ & $2.98^{* *}$ \\
\hline Quadratic regression & 1 & $0.63^{\text {ns }}$ & $0.08^{\text {ns }}$ & $0.04^{\text {ns }}$ & $0.28^{\text {ns }}$ & $0.006^{\mathrm{ns}}$ \\
\hline Salicylic acid (SA) & 3 & $5.88^{\text {ns }}$ & $0.068^{* \star}$ & $0.01^{\mathrm{ns}}$ & $0.26^{* *}$ & $0.06^{\mathrm{ns}}$ \\
\hline Linear regression & 1 & $2.67^{\mathrm{ns}}$ & $0.18^{\text {ns }}$ & $0.006^{\mathrm{ns}}$ & $0.59^{* *}$ & $0.03^{\text {ns }}$ \\
\hline Quadratic regression & 1 & $1.15^{\mathrm{ns}}$ & $0.02^{\text {ns }}$ & $0.024^{\text {ns }}$ & $0.06^{\text {ns }}$ & $0.01^{\mathrm{ns}}$ \\
\hline Interaction (SL x SA) & 12 & $12.03^{* *}$ & $0.021^{*}$ & $0.02^{\text {ns }}$ & $0.19^{* *}$ & $0.12^{* *}$ \\
\hline Blocks & 2 & $14.13^{* *}$ & $0.005^{\mathrm{ns}}$ & $0.03^{\text {ns }}$ & $0.05^{\text {ns }}$ & $0.14^{* *}$ \\
\hline Residue & 32 & 2.11 & 0.008 & 0.02 & 0.06 & 0.02 \\
\hline CV (\%) & & 4.73 & 5.10 & 12.33 & 19.96 & 4.71 \\
\hline
\end{tabular}

${ }_{n s,}^{*}{ }^{* *}$ respectively not significant, significant at $0<0.05$ and at $p<0.01$. CV: Coefficient of variation. 

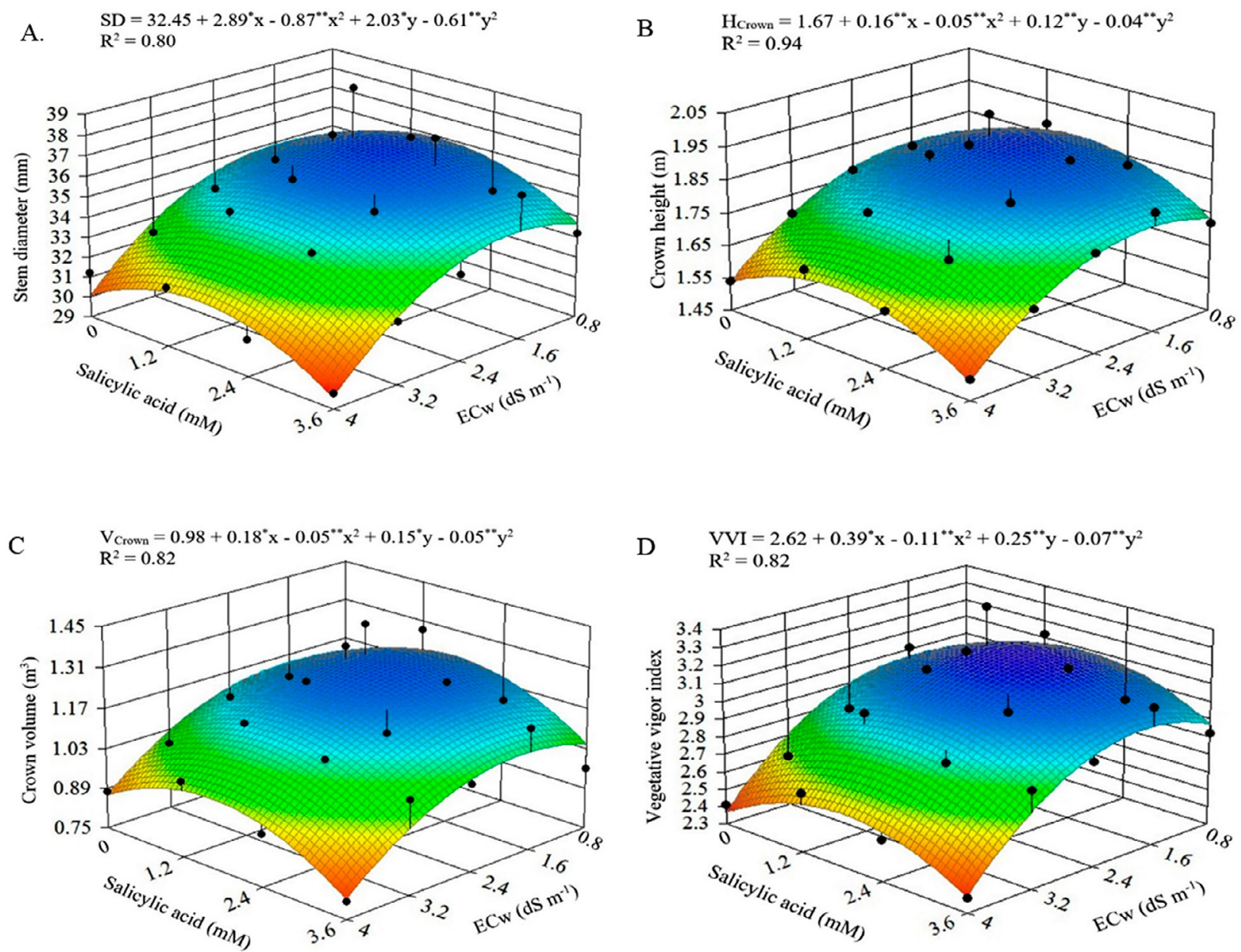

Figure 6: Response surface for stem diameter (A), crown height (B), crown volume (C) and vegetative vigor index (D) of soursop cv. Morada Nova as a function of the interaction between the electrical conductivity of irrigation water - ECW and the concentrations of salicylic acid, at 480 days after transplanting.

$X$ and $Y-E C W$ and salicylic acid concentration, respectively; ${ }^{*, * *}$ Significant at $p \leq 0.05$ and $p \leq 0.01$ by $F$ test.

\section{CONCLUSIONS}

Foliar application of salicylic acid at concentrations between 1.2 and $1.6 \mathrm{mM}$ mitigates the effects of salt stress on stomatal conductance, $\mathrm{CO}_{2}$ assimilation rate, transpiration and instantaneous carboxylation efficiency of soursop, at 480 days after transplanting. Spraying with salicylic acid at concentrations between 1.3 and $1.6 \mathrm{mM}$ induces acclimatization of soursop plants to salt stress, since the percentage of intercellular electrolyte leakage was reduced and the growth was favored by the application of salicylic acid, even when exposed to salinity. Irrigation with water above $0.8 \mathrm{dS} \mathrm{m}^{-1}$ reduces the relative water content in the leaves of soursop cv. Morada Nova.

\section{ACKNOWLEDGMENTS}

To the National Council for Scientific and Technological Development - CNPq for granting financial aid (Proc. CNPq 430525/2018-4) and to the Coordination for the Improvement of Higher Education Personnel - CAPES for granting the scholarship to the first author.

\section{REFERENCE}

ABBASZADEH, B. et al. Improving water use efficiency through drought stress and using salicylic acid for proper production of Rosmarinus officinalis L. Industrial Crops and Products, 144:e111893, 2020. 
AHMADI, M.; SOURI, M. K. Growth and mineral elements of coriander (Corianderum sativum L.) plants under mild salinity with different salts. Acta Physiologia Plantarum, 40(1):94-99, 2018.

AHMADI, M.; SOURI, M. K. Nutrient uptake, proline content and antioxidant enzymes activity of pepper (Capsicum annuum L.) under higher electrical conductivity of nutrient solution created by nitrate or chloride salts of potassium and calcium. Acta Scientiarum Polonorum Hortorum Cultus, 18(5):113-122, 2019.

AHMADI, M.; SOURI, M. K. Growth characteristics and fruit quality of chili pepper under higher electrical conductivity of nutrient solution induced by various salts. Journal of Agricultural Science, 42(1):143-152, 2020.

BATISTA, V. C. V. et al. Salicylic acid modulates primary and volatile metabolites to alleviate salt stress-induced photosynthesis impairment on medicinal plant Egletes viscosa. Environmental and Experimental Botany, 167:e103870, 2019.

BOUKRAÂ, D. et al. Effect of salinity on chickpea seed germination pre-treated with salicylic acid. Scientific Journal of Biological Sciences, 2(4):86-93, 2013.

CAVALCANTE, F. J. A. et al. Recomendação de adubação para o Estado de Pernambuco: $2^{a}$ aproximação. 3.ed., Recife: Instituto Agronômico de Pernambuco, 2008. 212p.

DIAS, A. S. et al. Gas exchanges and photochemical efficiency of West Indian cherry cultivated with saline water and potassium fertilization. Revista Brasileira de Engenharia Agrícola e Ambiental, 22(9):628-633, 2018.

EKBIC, H. B.; OZCAN, N.; ERDEM, H. Impacts of salicylic acid treatments on salt resistance of some American grapevine rootstocks. Fresenius Environmental Bulletin, 29(2):685$692,2020$.

ESAN, A. M. et al. Comparative effects of indole acetic acid and salicylic acid on oxidative stress marker and antioxidant potential of okra (Abelmoschus esculentus) fruit under salinity stress. Scientia Horticulturae, 216:278-283, 2017.

FERREIRA, D. F. SISVAR: A computer analysis system to fixed effects split plot type designs. Revista Brasileira de Biometria, 37(4):529-535, 2019.

FREITAS, A. L. G. E. de et al. Caracterização da produção e do mercado da graviola (Annona muricata L.) no estado da Bahia. Informações Econômicas, 43(1):23-34, 2013.

GUNES, A. et al. Salicylic acid induced changes on some physiological parameters symptomatic for oxidative stress and mineral nutrition in maize (Zea mays L.) grown under salinity. Journal of Plant Physiology, 164(6):728-736, 2007.
HATAMIAN, M. et al. Growth characteristics of ornamental Judas tree (Cercis siliquastrum L.) seedling under different concentrations of lead and cadmium in irrigation water. Acta Scientiarum Polonorum Hortorum Cultus, 18(2):87-96, 2019.

HATAMIAN, M. et al. Interaction of lead and cadmium on growth and leaf morphophysiological characteristics of European hackberry (Celtis australis) seedlings. Chemical and Biological Technologies in Agriculture, 7(1):1-8, 2020.

HERRERA-VÁSQUEZ, A.; SALINAS, P.; HOLUIGUE, L. Salicylic acid and reactive oxygen species interplay in the transcriptional control of defense genes expression. Frontiers in Plant Science, 6(1):171-179, 2015.

HUSSAIN, S. et al. Physiological analysis of salt stress behavior of citrus species and genera: Low chloride accumulation as an indicator of salt tolerance. South African Journal of Botany, 81:103-112, 2012.

JIMENEZ, V. M. et al. Identification of phenolic compounds in soursop (Annona muricata L.) pulp by high-performance liquid chromatography with diode array and electrospray ionization mass spectrometric detection. Food Research International, 65(1):42-46, 2014.

JASIM, N. S.; ATI, M. A. A. Effect of salycilic acid on antioxidant enzymes and biochemical contents of date palm plantlets (Phoenix dactylifera L.) under salt stress conditions. Indian Journal of Ecology, 47(2):378-382, 2020.

LIMA, G. S. de. et al. Water relations and gas exchange in castor bean irrigated with saline water of distinct cationic nature. African Journal of Agricultural Research, 10(13):15811594, 2015.

LIMA, G. S. de. et al. Gas exchange, chloroplast pigments and growth of passion fruit cultivated with saline water and potassium fertilization. Revista Caatinga, 33(1):184-194, 2020.

KHOSHBAKHT, D.; ASGHAREI, M. R. Influence of foliar-applied salicylic acid on growth, gas-exchange characteristics, and chlorophyll fluorescence in citrus under saline conditions. Photosynthetica, 53(3):410-418, 2015.

LEITE NETA, M. T. S. et al. Effect of spray drying on bioactive and volatile compounds in soursop (Annona muricata) fruit pulp. Food Research International, 124:70-77, 2019.

MAHMOUD, L. M. et al. The response of salt-stressed Valencia sweet orange (Citrus sinensis) to salicylic acid and methyl jasmonate treatments. Plant Physiology Reports, 26:1-15, 2021.

MEDEIROS, J. F. et al. Caracterização das águas subterrâneas usadas para irrigação na área produtora de melão da Chapada do Apodi. Revista Brasileira de Engenharia Agrícola e Ambiental, 7(3):469-472, 2003. 
MOGHADAMTOUSI, S. Z. et al. Annona muricata (Annonaceae): A review of its traditional uses, isolated acetogenins and biological activities. International Journal of Molecular Sciences, 16(7):15625-15658, 2015.

MOHAMED, I. A. A. et al. Stomatal and photosynthetic traits are associated with investigating sodium chloride tolerance of Brassica napus L. cultivars. Plants, 9(1):1-19, 2020.

MOHAMMADI, H. et al. Exogenous salicylic acid attenuates the adverse effects of salinity on some parameters related to photosynthesis of almond. Journal of Agricultural Science and Technology, 22(2):519-534, 2020.

MORAIS, M. B. de. et al. Multiple stresses on the oxidative metabolism of sugarcane varieties. Ciência Rural, 48(4):e20141487, 2018.

NAHAR, K. et al. Polyamines confer salt tolerance in mung bean (Vigna radiata L.) by reducing sodium uptake, improving nutrient homeostasis, antioxidant defense, and methylglyoxal detoxification systems. Frontiers in Plant Science, 7:e1104, 2016.

NAZAR, R. et al. Salicylic acid supplementation improves photosynthesis and growth in mustard through changes in proline accumulation and ethylene formation under drought stress. South African Journal of Botany, 98(1):84-94, 2015.

PORTELLA, C. R. et al. Desempenho de cultivares de citros enxertadas sobre o trifoliateiro 'Flying Dragon' e limoeiro 'Cravo' em fase de formação do pomar. Bragantia, 75(1):70-75, 2016.

POOJA, D.; SHARMA, K. D. Salicylic acid induced amelioration of salinity stress in mungbean. Saarbrücken: Scholar's Press, 2016. 108p.

RAJESHWARI, V.; BHUVANESHWARI, V. Salicylic acid induced salt stress tolerance in plants. International Journal of Plant Biology and Research, 5(3):1067-1073, 2017.

RICHARDS, L. A. Diagnosis and improvement of saline and alkali soils. Washington: U.S. Department of Agriculture USDA Handbook 60. 1954. 160p.

SAMADI, S.; HABIBI, G.; VAZIRI, A. Effects of exogenous salicylic acid on antioxidative responses, phenolic metabolism and photochemical activity of strawberry under salt stress. Iranian Journal of Plant Physiology, 9(2):2685-2694, 2019.

SÁNCHEZ, C. F. B. et al. Genetic diversity among soursop genotypes based on fruit production. Bioscience Journal, 34(1):122-128, 2018.

SÃO JOSÉ, A. R. et al. Atualidades e perspectivas das Anonáceas no mundo. Revista Brasileira de Fruticultura, 36(1):86-93, 2014.
SCOTTI-CAMPOS, P. et al. Physiological responses and membrane integrity in three Vigna genotypes with contrasting drought tolerance. Emirates Journal of Food and Agriculture, 25(12):1002-1013, 2013.

SILVA, A. A. R. et al. Salicylic acid as an attenuator of salt stress in soursop. Revista Caatinga, 33(4):1092-1101, 2020.

SILVA NETA, A. M. D. S. et al. Morphophysiology of the passion fruit 'BRS Rubi do Cerrado' irrigated with saline waters and nitrogen fertilization. Comunicata Scientiae, 12(1):e3456, 2021.

SOARES, L. A. A. et al. Physiological changes of pomegranate seedlings under salt stress and nitrogen fertilization. Revista Brasileira de Engenharia Agrícola e Ambiental, 25(7):453-459, 2021.

SOUANA, K. et al. Salt-tolerance in Vicia faba L. is mitigated by the capacity of salicylic acid to improve photosynthesis and antioxidant response. Scientia Horticulturae, 273(1):e109641, 2020.

SOURI, M. K.; BAKHTIARIZADE, M. Biostimulation effects of Rosemary essential oil on growth and nutrient uptake of tomato seedlings. Scientia Horticulture, 243:472-476, 2019.

SOURI, M. K.; HATAMIAN, M. Aminochelates in plant nutrition: A review. Journal of Plant Nutrition, 42(1):67-78, 2019.

SOURI, M. K.; TOHIDLOO, G. Effectiveness of different methods of salicylic acid application on growth characteristics of tomato seedlings under salinity. Chemical and Biological Technologies in Agriculture, 6:26, 2019.

SOUSA, J. R. M. et al. Impact of saline conditions and nitrogen fertilization on citrus production and gas exchanges. Revista Caatinga, 29(2):415-424, 2016.

TEIXEIRA, P. C. et al. Manual de métodos de análise de solo. 3.ed., Brasília: Embrapa Solos, 2017. 573p.

TUFAIL, A. et al. Salicylic acid induced salinity tolerance in maize (Zea mays L.). Pakistan Journal of Botany, 45(1):75-82, 2013.

UNITED STATES - Department of Agriculture. Keys to soil taxonomy. Natural Resources Conservation Service, 2014. 372p.

VELOSO, L. L. S. A. et al. Effects of saline water and exogenous application of hydrogen peroxide $\left(\mathrm{H}_{2} \mathrm{O}_{2}\right)$ on soursop (Annona muricata L.) at vegetative stage. Australian Journal of Crop Science, 13(3):472-479, 2019.

YUDINA, L. et al. A light-induced decrease in the photochemical reflectance index (PRI) can be used to estimate the energydependent component of non-photochemical quenching under heat stress and soil drought in pea, wheat, and pumpkin. Photosynthesis Research, 146:175-187, 2020. 